\title{
Contests about natural law in early enlightenment Copenhagen
}

\author{
Mads Langballe Jensen, Max Weber Kolleg, Universität Erfurt
}

\begin{abstract}
This article discusses the works of the first two lecturers on natural law in Copenhagen, Henrik Weghorst and Christian Reitzer. Contrary to the existing scholarship which characterises their works as derivative of either Grotius or Pufendorf, the article argues that the character and significance of these works can only be grasped when understood in light of the local intellectual traditions on which they built. Seen against this background, it becomes clear that Weghorst and Reitzer developed significantly different theories of natural law, disagreeing on such fundamental issues as the definition of law, the moral good, and the role of sociality in natural law. Following a tradition of Christian natural law in Kiel, Weghorst developed a theory of natural law fundamentally critical of the secularising theories of Grotius and Pufendorf, while Reitzer followed Pufendorf and his disciple Christian Thomasius in Halle. The article concludes by indicating how Weghorst's and Reitzer's works established the framework for discussions of natural law in the first decades of the eighteenth century, suggesting the need for further research into the significance of natural law for the early enlightenment in Denmark-Norway.
\end{abstract}

Keywords: Natural law; enlightenment; Samuel Pufendorf; Hugo Grotius; Denmark-Norway.

This is an uncorrected, pre-proof version. Please do not cite.

Published in History of European Ideas, available online:

http://www.tandfonline.com/doi/full/10.1080/01916599.2016.1182045

\section{Introduction}

The official political ideology in the Danish-Norwegian dual kingdom until the early eighteenth century is widely considered to have been a strongly theological divine right theory. It would, therefore, seem of great interest to know the circumstances and content of the first teaching of natural law in Copenhagen. This occurred during the years following a violent polemic between Christian Thomasius, the Leipzig jurisconsult and natural lawyer, and Hector Gottfried Masius, the court preacher to the Danish King Christian V, which culminated in Thomasius's writings being 
burned on the public square in Copenhagen by the executioner and contributed to his banishment from Leipzig to Halle. ${ }^{1}$ Nevertheless, the natural law theories of the first Danish teachers of the subject, Henrik Weghorst and Christian Reitzer, have not been the subject of detailed historical analysis. By offering such a study, this article aims to contribute to the scholarship on the history of post-Grotian natural law theorising in general and to the intellectual and political history of early enlightenment Denmark-Norway in particular.

\section{Henrik Weghorst and Christian Reitzer in the historiography}

Natural law as a prominent political discourse in the centuries following the publication of Hugo Grotius's De iure belli ac pacis in 1625 has received increasing scholarly attention in recent decades. The significance of natural law for the history of a wide range of disciplines, including moral and political philosophy, law, economics and theology, and a range of issues, including the development of the absolutist state, the relationship between church and state, theories of rights, secularisation and toleration in various forms of enlightenment, and in particular the distinctive contributions of Thomas Hobbes, Samuel Pufendorf and Christian Thomasius to so-called 'voluntarist' natural law have been investigated in detail. ${ }^{2}$

1 For detailed discussions of the polemics between Masius and Thomasius from a variety of perspectives, see Frank Grunert, 'Zur aufgeklärten Kritik am theokratischen Absolutismus. Der Streit zwischen Hector Gottfried Masius und Christian Thomasius über Ursprung und Begründung der summa potestas', in Christian Thomasius (1655-1728). Neue Forschungen im Kontext der Frühaufklärung, ed. Friedrich Vollhardt (Tübingen, 1997), 51-77; Frank Grunert, ‘»Händel mit Herrn Hector Gottfried Masio«. Zur Pragmatik des Streits in den Kontroversen mit dem Kopenhagener Hofprediger', in Appell an das Publikum: Die öffentliche Debatte in der deutschen Aufklärung 16871796, ed. Ursula Goldenbaum (Berlin, 2004), 119-74; Frank Grunert, 'Konfessionelle Konkurrenz und politisches Kalkül. Der dänische Hofprediger Hector Gottfried Masius', in Religion Macht Politik: Hofgeistlichkeit im Europa der Frühen Neuzeit, ed. Matthias Meinhardt et al. (Wiesbaden, 2014), 32340.

2 See e.g. Thomas Ahnert, Religion and the Origins of the German Enlightenment: Faith and the Reform of Learning in the Thought of Christian Thomasius (Rochester, 2006); Annabel S. Brett, Changes of State: Nature and the Limits of the City in Early Modern Natural Law (Princeton, 2011); Frank Grunert, Normbegründung und politische Legitimität: zur Rechts- und Staatsphilosophie der deutschen Frühaufklärung (Tübingen, 2000); Knud Haakonssen, Natural Law and Moral Philosophy: From Grotius to the Scottish Enlightenment (Cambridge, 1996); Knud Haakonssen, 'German Natural 
In line with this, scholars have emphasised the need for studies of how their thought was received, adapted, used and transformed in different places by their students. ${ }^{3}$ Thus it has been highlighted that so-called minor or second generation teachers of natural law often were even more influential than the canonical thinkers in shaping how natural law was taught and implemented in political reforms. ${ }^{4}$ This raises the further question of the existence of local 'dialects' of the discourse of natural law, and how such local 'dialects' were adapted to local concerns.

While there have been detailed studies of the reception and influence of post-Grotian natural law in Sweden, there are, however, no comparable studies of its reception in the other Scandinavian state, the double monarchy of Denmark-Norway. ${ }^{5}$ Despite the fact that central figures in early enlightenment Denmark-Norway, including Christian Reitzer, Ludvig Holberg and Andreas Hojer, are conventionally characterised as being influenced by Pufendorf and Thomasius the reception of the Pufendorfian-Thomasian natural law in Denmark-Norway has not been the subject of detailed historical enquiry, and neither has its place in early enlightenment thought. ${ }^{6}$

Law', in The Cambridge History of Eighteenth-Century Political Thought, ed. Mark Goldie and Robert Wokler (Cambridge, 2006), 249-90; Tim J. Hochstrasser, Natural Law Theories in the Early Enlightenment (Cambridge, 2000); Ian Hunter, Rival Enlightenments Civil and Metaphysical Philosophy in Early Modern Germany (Cambridge, 2001); Ian Hunter, The Secularisation of the Confessional State: The Political Thought of Christian Thomasius (Cambridge, 2007); Richard Tuck, Philosophy and Government, 1572-1651 (Cambridge, 1993); Richard Tuck, The Rights of War and Peace: Political Thought and the International Order from Grotius to Kant (Oxford, 1999).

3 The significance of Thomasius for the universities in Halle and Göttingen has been studied in detail in Notker Hammerstein, Ius und Historie: ein Beitrag zur Geschichte des historischen Denkens an deutschen Universitaten im spaten 17. und im 18. Jahrhundert (Gottingen, 1972).

4 Dominik Recknagel, 'Naturrecht in der Lehre. Naturrechtliche Vorlesungen an der FriedrichsUniversität zu Halle bis zum Jahr 1850', in ,,Vernunft, du weiß allein, was meine Pflichten sind!’' Naturrechtslehre in Halle, ed. Dominik Recknagel and Sabine Wöller (Halle (Saale), 2013), 12. 5 Bo Lindberg, Naturrätten i Uppsala 1655-1720 (Uppsala, 1976); Per Nilsén, Att 'stoppa munnen till på bespottare': den akademiska undervisningen i svensk statsrätt under frihetstiden (Lund, 2001). For the reception of Christian Thomasius in the Baltic, see Hanspeter Marti, 'Christian Thomasius und der Pietismus im Spiegel ihrer Wirkungsgeschichte. Zur philosophiegeschichtlichen Bedeutung der Thomasius-Rezeption im Baltikum', in Christian Thomasius (1655-1728). Neue Forschungen im Kontext der Frühaufklärung, ed. Friedrich Vollhardt (Tübingen, 1997), 235-50.

6 For important suggestions in this direction, however, see Kasper Risbjerg Eskildsen, 'Print, Fashion, and the Making of the Enlightenment Philosopher', in Northern Antiquities and National Identities. 
Henrik Weghorst and Christian Reitzer are usually discussed together in the scholarship as the two responsible for introducing modern, that is, post-Grotian, natural law. Like many other authors from the time, however, they are primarily set as background to the pre-eminent figure in the Danish-Norwegian enlightenment, Ludvig Holberg. Accordingly the content of their natural law works is rarely discussed, with scholars contending themselves with characterising them as following one or other of the 'great thinkers'. Edvard Holm, in what is still considered his classical study of Ludvig Holberg's political views, characterises both thinkers as following Pufendorf. ${ }^{7}$ Kåre Foss's study of Ludvig Holberg's theory of natural natural law against, as the title says, 'its intellectual background', likewise characterises all Danish natural law before Holberg, that is Weghorst and Reitzer, as 'diluted Pufendorf'. ${ }^{8}$ The most recent account of the history of law at Copenhagen University introduces a slight variation, characterising Reitzer as following Grotius and Pufendorf while claiming that Weghorst's work on natural law was 'entirely orientated towards Grotius.'9

From surveying the scholarship, then, one gets the sense that both Weghorst and Reitzer offered more or less the same thing: the first brief - and Latin - introductions to natural law on the

Perceptions of Denmark and the North in the Eighteenth Century. Symposium held in Copenhagen August 2005, ed. Knud Haakonssen and Henrik Horstbøl (København, 2008), 126-44; Knud Haakonssen, 'Holbergs Pufendorf - men hvilken Pufendorf?', in Ludvig Holbergs naturret, ed. Jørgen Sejersted and Eiliv Vinje (Oslo, 2012), 31-45; Sebastian Olden-Jørgensen, “"Saa at jeg har efterlevet en Historieskrivers uden at overtræde en Borgers Pligt" - naturret og historie i Holbergs behandling af enevældens indførelse 1660', in Ludvig Holbergs naturret, ed. Jørgen Sejersted and Eiliv Vinje (Oslo, 2012), 118-39; Sebastian Olden-Jørgensen, 'Scandinavia', in European Political Thought, 1450-1700: Religion, Law and Philosophy, ed. Howell A. Lloyd, Glenn Burgess, and Simon Hodson (New Haven, 2007), 300-331. The standard account of enlightenment philosophy in Denmark is given as a history of of the eclipse of a conservative, Aristotelian philosophy by Wolffianism followed by French and British influences as well as Kantianism. Carl Henrik Koch, Dansk oplysningsfilosofi, 1700-1800 (København, 2003). But see also Koch, 'Dänemark und Norwegen', in Die Philosophie des 18. Jahrhunderts, ed. Helmut Holzhey and Vilem Mudroch, vol. 5: Heiliges Römisches Reich Deutscher Nation, Schweiz, Nord- und Osteuropa, Zweiter Halbband (Basel, 2014), 1509-11, which briefly mentions Thomasius's influence as well.

7 Edvard Holm, Holbergs statsretslige og politiske synsmåde (Kjøbenhavn, 1879), 17, 18n1.

$8 \quad$ Kåre Foss, Ludvig Holbergs naturrett på idéhistorisk bakgrunn (Oslo, 1934), 175.

9 Ditlev Tamm, Juraen på Københavns Universitet 1479-2005 (København, 2005), 65. 
basis of Grotius and Pufendorf, soon to be superseded by Ludvig Holberg's great Danish introduction to natural law on the basis of Grotius, Pufendorf and Thomasius. However, Grotius' and Pufendorf's theories of natural law were by no means identical or indeed necessarily compatible, and so, how the two were combined would prove a decisive difference. Moreover, 'following' or 'being orientated towards' Grotius or Pufendorf, or a combination of the two, would always involve an act of interpretation, adaptation and use, which would influence the 'Grotian' and 'Pufendorfian' natural law thus developed. It will be shown that Weghorst and Reitzer in fact developed two fundamentally different positions on natural law reflecting the different local academic contexts and discourses in which they were educated, Kiel and Halle.

\section{The institutional context of natural law in Denmark-Norway}

Although the absolutist constitution of Denmark-Norway, the Lex Regia, of 1665 was significantly influenced by the contractual framework of Grotian natural law, the constitution was kept secret and only published in 1709. The official ideology was one of divine right absolutism, as represented e.g. by the bishop Hans Wandal and the court preacher Hector Gottfried Masius. ${ }^{10}$ While Masius's intentions with Interesse principum circa religionem Evangelicam (The Advantage of the Evangelical Religion to the Princes), the work which sparked off the polemics with Thomasius, were primarily confessional, it included arguments highly critical of 'secular' natural law. Worried by the prospects of increased Calvinist immigration following the revocation of the edict of Nantes, he warned against the subversive nature of Calvinist religious doctrine, advising the King that his best interest lay in maintaining the purity of Lutheran doctrine among his subjects. ${ }^{11}$ As part of his argument that political order could only be maintained on the grounds of the true Lutheran religion, Masius had explicitly denied the validity of a natural law on the basis of reason. Divorced from revealed religion, natural law was a 'maimed and mutilated doctrine'. The duties towards God were taught exclusively by religion, while those towards oneself and others were determined partly by right reason and partly by religion. As such revealed religion should take 'first place' in any doctrine of natural law. ${ }^{12}$

10 For an account of political thought and ideology in Denmark-Norway and Sweden, see OldenJørgensen, 'Scandinavia', for the Lex Regia, Wandal and Masius, see pp. 322-6.

11 For an analysis of Masius's confessional agenda, see in particular Grunert, 'Konfessionelle Konkurrenz und politisches Kalkül'.

12 Hector Gottfried Masius, Interesse principum circa religionem Evangelicam ad serenissimum ac 
Despite Masius highly critical remarks concerning the discipline of natural law in a work that received official support, steps were being taken to introduce precisely this academic subject in the University of Copenhagen, seemingly as part of a general endeavour to raise the quality of education in the capital. A draft of new university statutes from 1691 stipulated that the professor of law 'should explain Jus Naturae and Gentium'. ${ }^{13}$ Although teaching of natural law was first codified in the new statutes for the University of Copenhagen in 1732, with a chair in 'Jus Naturae et Gentium as well as Jus Publicum' and moral philosophy, ${ }^{14}$ natural law was taught in the 1690 s at the modern (albeit short-lived) Knights' Academy in Copenhagen and probably at the University as well.

The Knights' Academy in Copenhagen was founded in 1691, on the model of the knights' academies in the German lands. ${ }^{15}$ It seems Christian Reitzer had been first choice as professor of law, but (probably because of his appointment at the university) Weghorst was appointed in the spring of 1692 instead. ${ }^{16}$ In a report of his teaching from October 1693 Weghorst declares his intention to turn to the law of nature and nations. ${ }^{17}$ The following year Weghorst had completed a manuscript textbook on natural law, the Compendium Juris naturce (Compendium on natural law),

potentissimum Danice Regem (Hafniae, 1687), 3f.

131691 draft of new university statutes printed in William Norvin, Københavns Universitet $i$ Reformationens og Orthodoxiens Tidsalder, vol. 2 (København, 1940), 86.

141732 university statutes printed in Ibid., 2:114. On the statutes, see Tamm, Juraen på Københavns Universitet, $70 \mathrm{ff}$.

15 For a general account of the history of the Knights' Academy and the sources pertaining to it, see William Norvin, 'Det ridderlige Akademi i København', in Historiske Meddelelser om København, vol. 2. rk. 5. bd. (København, 1931), 103-235; William Norvin, 'Aktsstykker til Oplysning om det ridderlige Akademi i København 1690-1710', in Danske Magazin, 6. rk. 5. bd. (København, 1930), 1169.

16 Norvin, 'Det ridderlige Akademi i København', 206; Norvin, 'Aktstykker', 19, 134

17 Norvin, 'Aktstykker', 68. For biographical information, see 'Heinrich Weghorst', Dansk Biografisk Leksikon Online, accessed 2 February 2016, http://denstoredanske.dk/Dansk_Biografisk_Leksikon/Samfund,_jura_og_politik/Jura/Jurist/ Heinrich_Weghorst; Johann Moller, Cimbria literata (Hafniae, 1744), I:715; Johann Heinrich Zedler, Grosses vollständiges Universal Lexicon aller Wissenschaften und Künste, 1731, 53:1917f.; Tamm, Juraen på Københavns Universitet, 65. 
which likely formed the basis of his lectures on the subject. ${ }^{18}$ The first three parts of the collegium provided the material for a dissertation presided over by Weghorst on $19^{\text {th }}$ March 1696, the Compendii juris naturce, Dissertatio prima (Compendium on natural law, first dissertation).${ }^{19}$ In 1693 Weghorst had been appointed professor designatus in the Faculty of Philosophy at the University, where he became ordinary professor sometime between 1698 and 1700. In 1704 a personal chair in 'Juris \& moralis scientiae' was created for Weghorst, a post which he held to his death in $1722 .{ }^{20}$

Having been professor designatus in both philosophy and law since 1689, and having studied in Halle in 1690-2, Christian Reitzer returned to take up the chair as professor of law at Copenhagen University in 1692 (the only chair in law until 1732), a post he held until $1723 .^{21}$ According to the official catalogue of public lectures at the university, Reitzer taught natural law in $1700-01 .^{22}$ Although there is a gap in the catalogue for the years between 1686 and 1698 , there is some evidence that Reitzer taught natural law earlier in the 1690s as well. In 1694 Reitzer published the short (and incomplete) Positiones ex jure divino, sive universali, sub proesidio Christiani Reitzer defendent juvenes (Subjects from divine or universal law, which some most noble and learned youths will defend, presided over by Christian Reitzer), which, considering the title, is likely to have grown out of his teaching. ${ }^{23}$ The topic of universal divine law proved a continuing topic in Reitzer's teaching, and in 1702 he published a revised and much longer version of the work, (although also incomplete) Positionum ex jure divino universali partis primae caput primum (Subjects from divine universal law, part one chapter one), which was explicitly conceived

18 The manuscript collegium bears the inscription 'haec scripseram A. 1694' Henrik Weghorst, 'Compendium Juris naturæ' (Thott 909 4일 1694), final page.

19 Henrik Weghorst, Compendii juris naturce, Dissertatio prima (Hafniae, 1696).

20 Ejvind Slottved, Larestole og loerere ved Københavns Universitet 1537-1977 (København, 1978), 90, $139,213$.

21 Ibid., 88, 213. For biographical information, see 'Christian Reitzer', Dansk Biografisk Leksikon Online, accessed 2 February 2016, http://denstoredanske.dk/Dansk_Biografisk_Leksikon/Kunst_og_kultur/Litteratur/Bogsamler/ Christian_Reitzer.

22 Lectiones publicae Professorum in Universitate Hauniensi (Hafniae, n.d.), 1700-01.

23 Christian Reitzer, Positiones ex jure divino, sive universali, sub prcesidio Christiani Reitzer defendent juvenes (Hafniae, 1694). 
as an aid to students studying natural law. ${ }^{24}$ In addition, Reitzer had published the dissertation De obligatione sontium ad subeundam poenam dissertatio (On the obligation of the guilty to submit to punishment) in 1793, in part a criticism of Hobbes's position on the subject on the basis of Pufendorfian natural law. ${ }^{25}$

Weghorst's and Reitzer's careers, then, were parallel: they were both appointed professors of law in the early 1690s and both devoted significant parts of their academic endeavours to teaching the new post-Grotian natural law, Weghorst at the academy and the university in the faculty of philosophy, and Reitzer in the faculty of law. It is therefore not surprising that they have been mentioned together in the existing historiography touching on natural law in DenmarkNorway, and perhaps this parallel in their academic careers has led scholars to see parallels also in the substance of their teaching. However, as we shall see in the following, Weghorst and Reitzer developed decidedly different theories of natural law.

\section{Pufendorfian natural law: Christian Reitzer's Positionum ex iure divino universali}

Christian Reitzer's works on natural law reflect the fact that he had studied in Halle in 1690-2 under Christian Thomasius. In 1688, Thomasius had published his Institutes of Divine Jurisprudence, which was largely a defence and elaboration of Pufendorf's theory of natural law. ${ }^{26}$ Thomasius lectured on his Institutes in 1691 (in private collegium) and it is likely that Reitzer attended at least some of these, and perhaps even discussed issues of natural law with Thomasius himself. ${ }^{27}$ In the invitation to this collegium, which was published as an introduction to later editions of the Institutiones, Thomasius gave a brief account of the history and present state of the discipline of natural law, highlighting the contributions in particular of Grotius and Pufendorf and explaining how his own Institutes were intended as a defence of Pufendorf against the Leipzig theologian Valentin Alberti. The introduction to the collegium is interesting for our purposes as it provides a succinct summary of the perspective on natural law which Reitzer would take with him

24 Christian Reitzer, Positionum ex jure divino universali partis primce caput primum, seu de iis, quce universo in iure prcecognita esse debent (Hafniae, 1702).

25 Christian Reitzer, De obligatione sontium ad subeundam poenam dissertatio (Hafniae, 1693).

26 Christian Thomasius, Institutes of Divine Jurisprudence: With Selections from Foundations of the Law of Nature and Nations, ed. Thomas Ahnert (Indianapolis, 2011), 'Introductory dissertation', 13ff.

27 Decades later Thomasius would recall Reitzer's stay in Halle in conversation with a travelling Danish student; cf. Vello Helk, Dansk-norske studierejser, 1661-1813, vol. 1 (Odense, 1991), 91. 
from Halle to Copenhagen as well as the issues at stake between him and Weghorst.

Thomasius presented the recent advances in the discipline of natural law as part of a general progress of learning in the Protestant universities during the second half of the seventeenth century, abolishing the 'servitude' that had characterised previous centuries. Although the 'scholastics among the papists' had written numerous works on natural law they had completely confused Scripture, nature, and human laws in a way more likely to confuse 'a reasonable human being' than anything else. What was more, this form of scholastic natural law had been appropriated by the Protestants, as evidenced by the works of the Tübingen theologian Johann Adam Osiander. ${ }^{28}$

According to Thomasius, it was Hugo Grotius who first had begun to rescue the "noble discipline' of natural law and clean the 'dust of the schools' from it and thus given the discipline a high standing. ${ }^{29}$ His books had been very well received in the universities (though obscured by commentaries), but this, Thomasius argued, was only because Grotius was the first to 'break the ground', for, being first, his breach with tradition was insufficient. Although Grotius sought the law of nature in human nature, he retained many scholastic errors in his 'definition of the law of nature'. These included the doctrines that things prohibited by the law of nature 'were morally bad in themselves and prior to divine will' and the 'etiamsi daremus' principle that natural law would obligate even if God did not exist. ${ }^{30}$

That Thomasius was right about the reasons for the good reception of Grotius was brought out by the violent abuse and polemics that met Pufendorf when he had attacked these scholastic remnants in his 1672 De iure naturae et gentium libri octo (On the Law of Nature and Nations). ${ }^{31}$ It

28 Christian Thomasius, 'Christian Thomas [...] Eröffnet Der Studierenden Jugend in Halle Ein Collegium Privatum Uber seine Institutiones Jurisprudentiae Divinae', in Institutionum Jurisprudentice Divince Libri Tres (Halæ, 1710), 74f. For an account of Osiander's 'Christian natural law', see HansPeter Schneider, Justitia universalis: Quellenstudien zur Geschichte des 'Christlichen Naturrechts' bei Gottfried Wilhelm Leibniz (Frankfurt am Main, 1967), 151-9.

29 Thomasius, 'Collegium privatum', 76.

30 'wie er denn auch in Definition des Rechts der Natur der Schul-lehrer ihre Doctrin, dass die durch das Recht der Natur verbothene Dinge per se \& antecedenter ad voluntatem divinam böse wären/ mit beybehalten / auch nach ihrer Anleitung geschrieben, dass das Recht der Natur die Menschen verbinden würde / wenn gleich kein GOtt seyn oder sich umb die menschlichen Händel nicht bekümmern solte.' Ibid., 76f.

31 Samuel Pufendorf, De iure naturae et gentium libri octo (Lund, 1672). 
was thus a common characteristic of all the anti-Pufendorfian works that they criticised sociality as the 'principium cognoscendi of the law of nature' and sought to reassert the existence of a 'lex aeterna' and that certain things were good or bad in themselves prior to the divine will. In his Institutiones, Thomasius had criticised these doctrines, defended Pufendorf's magnum opus and asserted sociality as the principle of natural law, in particular against the attacks by the Leipzig theologian Valentin Alberti. ${ }^{32}$

Reitzer's Positionum is structured as introductory discussions of key concepts falling under the category 'Right in general' (Ius in genere). These include, the meaning of the terms 'right', 'law', 'command' and 'obligation', and accordingly also the moral nature of man, moral status, and other relevant issues. The work is clearly incomplete as Reitzer in several places referred to a second chapter which would discuss the principles of natural and universal positive divine law. ${ }^{33}$ Nevertheless the often detailed discussions mean that Reitzer touched upon a wide range of issues to substantiate his definitions and their implications, drawing predominantly on the early chapters of Pufendorf's De iure and De officio hominis et civis iuxtam legem naturalem (On the Duty of Man and Citizen According to Natural Law), ${ }^{34}$ Thomasius's Institutes and Grotius's De iure belli ac pacis. The work thus provides ample material to show that he, like Thomasius, followed the fundamentals of Pufendorf's position, and precisely those that were considered most controversial at the time: his moral voluntarism, the doctrine of entia physica and moralia and imposed statuses, and the injunction of sociality as the foundational precept of natural law. ${ }^{35}$

Reitzer signals his commitment to Pufendorf's and Thomasius's advances in the theory of natural law by prefacing the Positionum with a brief account of the importance and development of

32 'Alle Scripta Anti-Pufendorffiana zielen dahin / dass die Socialität kein Principium cognoscendi des Rechts der Natur seyn könne. [...] Hiernechst haben die meisten sich angelegen seyn lassen / die ex lege aeterna hergeleitete convenientiam cum sanctitate divina antecedenter ad voluntatem divinam, oder die sogenandte perseitatem turpitudinis \& honestatis in objecta Juris naturae, die von dem Herrn von Pufendorff von ihrem Thron ware verstossen worden / wieder auff denselben zu heben.' Thomasius, 'Collegium privatum', 79.

33 Reitzer, Positionum ex jure divino, pos. 1(c).

34 Samuel Pufendorf, De officio hominis et civis juxta legem naturalem libri duo (Lund, 1673).

35 For an analysis of these issues in Pufendorf, see Hunter, Rival Enlightenments, chapter 4, in particular pp. 162ff. 
the discipline similar to the one given by Thomasius. ${ }^{36}$ Among the greatest advances of the modern age was that the 'discipline of universal divine law' had been put on a firm foundation. Grotius was the first properly to distinguish natural and positive law. On this basis, the 'clouds' with which the scholastic moralists had obscured Scripture were dispersed, the boundaries between (divine) natural law and divine positive law were defined and each thus put on a secure basis. ${ }^{37}$ However, this did not mean that Reitzer was primarily a 'Grotian', and in fact criticised Grotius along lines suggested by Pufendorf.

The first criticism of Grotius came early in the work, where Reitzer adopted Pufendorf's voluntarist and anti-scholastic definition of law as a command issuing from a superior. In a note to positio 5, Reitzer explained that this definition was in contrast to 'what Grotius seems to establish with the scholastics, when in the Prolegomena to De iure belli ac pacis $\S 11$ he says that "the law of nature would obligate even if God did not exist". ${ }^{38}$ In elaborating on this definition in the following positio, Reitzer further argued that since a law is the command of a superior, and since God has no superior, God cannot be subject to law. On this basis he criticised a doctrine held not only by Catholic scholastics, but also, as Reitzer undoubtedly knew, by many Protestant natural lawyers (including, as we shall see, Henrik Weghorst): 'And from this follows that the "eternal law" according to which the scholastics say God acts is a pure figment of the imagination.' ${ }^{39}$ Despite his praise of Grotius in the preface, then, Reitzer, like Pufendorf and Thomasius, saw his break with scholasticism as incomplete in crucial respects. Indeed, Reitzer also followed the implications of Pufendorf's voluntarism for his understanding of man's moral nature and the character and principles of natural law. Of these two central topics, the first received the most thorough discussion, as the discussion of the second belonged to a later part of the work.

Reitzer's discussion of moral status, in which he followed Pufendorf's distinction between physical and moral entities, came in positio 23 on how man can hold rights. ${ }^{40}$ 'Rights belong to a

36 For a discussion of the importance of such histories, see Hochstrasser, Natural Law Theories in the Early Enlightenment, 66, 137.

37 Reitzer, Positionum ex jure divino, [first unnumbered page headed 'L.S.'].

38 'Contra quam cum Scholasticis statuere videtur Grotius, dum in Prolegominis Jur. B. \& P. §11. Legem Naturalem obligaturam fore dicit, etiamsi daremus non esse Deum.' Ibid., pos.5(a).

39 'Et hinc sequitur, aeternam illam legem, secundum quam agere Deum Scholastici dicunt (b), merum solummodo esse figmentum.' Ibid., pos.6.

40 Reitzer here referred the reader to Pufendorf's De iure (bk. 1, ch. 1 and bk. 2, ch. 2), De officio (bk. 2, 
person', Reitzer explained, 'not as a physical but as a moral person, and indeed as a man considered as existing in a certain status.' A status, then, was a given man's 'place and condition in communal life', according to which a person hold certain rights and obligation granted to him by a superior. ${ }^{41}$ Reitzer emphasised two aspects of this definition of person and status. First, the complete separation between man's physical nature and moral personhood. Thus, a single natural person could 'enjoy several statuses', such as 'father in the house, advisor in the court, senator in the senate, captain in the army etc.', along with the different rights and obligations of each as long as they were compatible. Moreover, several natural persons could be considered as one 'complex person' if united in moral status, such as states, churches and universities. Second, although status was a moral quality superimposed on man, man was never in fact without a particular moral status of one sort or the other. For at the very least man was in a natural state or state of humanity, in which he enjoyed certain rights and obligations, itself a status imposed on man as a moral personby God. $^{42}$

Natural law, then, was the law God had imposed on man to govern his behaviour in the 'natural state', bestowing on man certain rights and obligations. ${ }^{43}$ As mentioned, Reitzer did not discuss natural law as an independent subject of a positio, but his position is evident from places where natural law is touched upon in discussing other issues. Thus, in positio 32 Reitzer made it clear that sociality, by which the temporal happiness of mankind is maintained, was the foundation of natural law. ${ }^{44}$ From the fact that human nature was such that it could not be maintained without this law, one should conclude that God in fact obligated men to obey it: 'By the very act by which

ch. 1) and Thomasius's Institutiones (bk. 1, ch. 2).

41 'Jus autem (a) personae competit, non qua illa physice, sed qua moraliter (b) \& quidem tamquam homo in statu aliquo (c) existens consideratur. Status enim est ipse cujusvis hominis in communi vitae locus \& conditio' Reitzer, Positionum ex jure divino, pos.23.

42 '... abstrahendo ab ista moralitate, nullum ipsi jus competit, ut ut inde non sequatur, dari hominem, qui in nullo existat statu. Eo ipso enim, quo homo est, in statu quoq; humanitatis degit; at hic status propria sua etiam habet jura.' Ibid., pos.23(b), cf. (dI). Cf. Pufendorf, De iure, bk. 1. ch. 2, §§7\&12.

43 This was not just in a hypothetical state of nature, or the state of nature obtaining between states, but also the status man enjoyed in virtue of being human. on the various meanings of the term 'status naturalis', see Reitzer, Positionum ex jure divino, pos.23(dI-III).

44 'Cum enim socialitas, qua utique temporaria humani generis continetur felicitas, en eo consistat, ut sarta tectaque mortalibus talia sua sint jura, consequens est, haec in universum non magis, quam ipsas naturae leges, quae quidem conservandae socialitati[s] sunt latae, mutari tollique posse.' Ibid., pos.32. 
God the Creator of all things imposed on us a certain nature, which cannot be preserved without observing the laws of nature, the observation of these laws is understood to be imperatively imposed on us. ${ }^{45}$

In the Positionum ex jure divino universali, then, Reitzer was effectively in the process of constructing an introduction to Pufendorfian natural law. This included presenting precisely the aspects of this system which were most controversial at the time, the strict distinction between moral theology and natural law, the strong moral voluntarism and doctrine of imposed statuses or personae, and sociality as the foundation of natural law. The wider significance of this becomes clear, when we consider the religious and political aims of Pufendorf's works on natural law. As Ian Hunter has argued, Pufendorf had developed a 'detranscendentalised' theory of natural law to promote the 'secularisation' of the early modern state. In doing so Pufendorf had reformed the discipline of natural law that had held together a philosophical-theological synthesis that was centred in the faculties of theology and helped secure the influence of theologians in the politicalreligious constitution of the early modern confessional state. Pufendorf's works on natural law thus had important consequences for the nature of the state and were part of a contest between two professional groups about the authority to determine the social and political order of the state, the theologians or the jurists. ${ }^{46}$ In adopting the more radical aspects of Pufendorf's theory of natural law, Reitzer was simultaneously championing this political programme.

\section{Christian natural law: Weghorst's Compendii iuris naturae dissertatio prima}

At first glance, Weghorst's Compendii iuris naturae dissertatio prima might give the impression that Weghorst was indeed following Grotius or Pufendorf in his theory of natural law. The work begins with a substantial quotation from Grotius's De iure belli ac pacis defining ius naturae, and contains further quotations from Grotius in key places. Likewise, the structure of the work bears some resemblance to Pufendorf's De officio hominis et civis, the first chapter concerning the definition of natural law, followed by chapters on the principles of natural law and on the duties towards God. This structure of discussing duties towards oneself, God, and other persons was,

45 'Eo ipso ergo, quo Deus rerum omnium Creator naturam nobis indidit, quae sine observatione legum naturalium salva esse nequit, earum etiam observationem pro imperio nobis injunxisse intelligitur.' Ibid., pos.33(f).

46 Hunter, Rival Enlightenments, 150, 162f, 195; Haakonssen, 'German Natural Law', 261f. 
however, quite conventional in the Lutheran world. ${ }^{47}$ Moreover and more significantly, a closer look at Weghorst's argumentation quickly reveals that his position departed significantly from both Grotius and Pufendorf. In fact, as will be shown, Weghorst's Compendium exhibited all the characteristics of 'anti-Pufendorfian' works of natural law identified by Thomasius, and this reflected the academic environment in which Weghorst had received his university training.

Weghorst had received his university education at Kiel University in the Duchies of Schleswig-Holstein, where he enrolled in 1670. After some years, he did the usual European tour, to Germany, Italy and France, before before returning to Kiel where he became Dr. Jur. in 1681. Natural law had been taught at Kiel University since it was founded in 1665. During Weghorst's studies there, the professor of natural law was Samuel Rachel, a prominent representative of what has been termed 'Christian natural law'. ${ }^{48}$ This tradition, which also included authors such as Johann von Felde, Caspar Ziegler, Johann Adam Osiander, and Valentin Alberti, sought to reestablish natural law on a Christian foundation against the secularising theories of natural law developed by Grotius and Hobbes, and later Pufendorf and Thomasius. Rachel was one of the thinkers, also including Pufendorf and Conring, whom Baron von Boineburg approached to produce a system of natural law. ${ }^{49}$ Weghorst had ample opportunity to become acquainted with the tradition of 'Christian natural law': according to the Catalogus lectionum in Academia ChristianAlbertina Kiliensi, Rachel taught courses on 'Jus naturale' in 1671, on 'Jura naturae \& arbitraria' in 1672, on Grotius's De iure belli ac pacis in 1673, 'Juris naturae \& gentium doctrina' in 1674, his Dissertationes de Jure naturae in 1675, and 'Jurisprudentia universalis' in 1676-7..$^{50}$

47 Found, for instance, in Samuel Rachel and H. G. Masius.

48 See Hans-Peter Schneider, 'Christliches Naturrecht', in Die Philosophie des 17. Jahrhunderts, ed. Helmut Holzhey and Wilhelm Schmidt-Biggemann, vol. 4: Das Heilige Römische Reich Deutscher Nation, Nord- und Ostmitteleuropa, Zweiter Halbband (Basel, 2001), 813-35; Schneider, Justitia universalis, for Rachel pp. 208-223; Hunter, Rival Enlightenments, 132-4. Rachel's 1676 De jure naturae et gentium dissertationes was included in the Carnegie series on international law as an important alternative to Pufendorf's doctrine of the law of nations, Samuel Rachel, De Jure Naturae et Gentium Dissertationes (1776), ed. Carl Ludwig Bar, trans. John Pawley Bate, 2 vols, Classics of international law (Washington, 1916).

49 Rachel, Dissertationes, I§101; Hochstrasser, Natural Law Theories in the Early Enlightenment, 47.

50 Catalogus lectionum in Academia Kiliensi, Personal- und Vorlesungsverzeichnis der ChristianAlbrechts-Universität zu Kiel, n.d., http://www.uni-kiel.de/journals/receive/jportal_jpjournal_00000001. 
In the construction of his natural law theory, Rachel discussed several 'modern' works, but in particular Hugo Grotius's De iure belli ac pacis which he interpreted through William Grotius's De principiis iuris naturalis. Rachel drew extensively on certain scholastic doctrines combined with extensive use of Aristotle and Cicero, as was common to much Protestant natural law theorising in the wake of Grotius. Central to Rachel's theory was the view that certain things or actions were eternally and in themselves good and provided a fundamental framework for God's creation. Natural law was the means by which man was obligated to do those things good in themselves and avoid those bad in themselves: 'and hence it is that that which the Law of Nature enjoins or forbids is not, respectively, good or bad merely because God has of his free will decided to enjoin the one or forbid he other; but since the former is in its essence wholly good and the latter wholly bad, God could not but forbid this and enjoin that. ${ }^{51}$

In further determining the specific precepts of natural law, Rachel turned first to discuss the alternative 'systems' for determining these laws. Having presented contemporary theories, including those of Selden, Sharrock, Cherbury, Cumberland and Hobbes, he finally turned to Aristotle's Posterior Analytics for a method for the discipline of natural law or 'scientia philosophiae moralis' ${ }^{52}$ Having set down as first principles the existence of God, divine providence and the immortality of the soul, Rachel on this basis developed the laws of nature governing man's society with God and with other humans.

In order to determine these, Rachel argued, one must first ask 'What is the ultimate end of

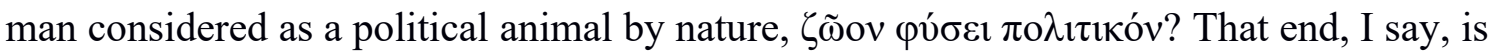
conformity or congruence of the human will, which is the proximate principle of moral conduct, with the Divine will, as expressed in natural laws. ${ }^{53}$ In so doing man would not only express the

51 'Hujus igitur Legis Aeternae radii sunt Leges Naturales, quas nobis Ratio, divinae particula aurae, indicat, persuadet ac promulgat. Atque hinc est, quod quidquid Jure Naturae, vel praecipitur vel vetatur, illud non bonum nec malum est ideo quod Deus illud libere voluit praecipere, hoc vetare; sed quia intrinsecus illud omne bonum, $\&$ hoc omne malum est, Deus illud non potuit non praecipere, hoc vetare. Ut ita simul intelliges, quo pacto hoc jus divinum Naturale, a Jure divino arbitratio differat. Grot I.c.1.n.10 \& 15; Wilh.Grot.de.princ.cap.3.n.2.’ Rachel, Dissertationes, I:§32.

52 Ibid., I§114.

53 'Discipiendum itaque primo omnium erit, quis sit Hominis finis ultimus, quatenus ille ut $\zeta \tilde{\omega}$ ov $\varphi v ́ \sigma \varepsilon ı$ $\pi \mathrm{o} \lambda \iota \tau \iota \kappa o ́ v$, animal natura civile, consideratur. Hunc finem esse dico, conformitatem seu convenientiam voluntatis humanae, quae actionum moralium proximum est principium, cum voluntate divina legibus 
'primeval image of God' but also, Rachel asserted with a reference to William Grotius, 'attain the utmost perfection of which he is capable in this life. ${ }^{54}$ In elucidating what this meant in more specific terms, Rachel resorted to the Roman law dictum 'suum cuique tribuere': 'Man, therefore, attains this Assimilation and Perfection when he renders to God, to himself, and to his fellows the things which are due to them respectively, and avoids the contrary. ${ }^{, 55}$ Finally, in answering the question of what the due - the 'praestanda' - according to natural law amounted to, Rachel found no better answer than piety to God and the Aristotelian virtues to others in human society. ${ }^{56}$

Although Weghorst never cites Rachel in his Collegium iuris naturae, there are, as will be shown, several points of similarity on central issues in their theories of natural law. Weghorst thus drew on several Grotius-commentators from the seventeenth century that had endeavoured to 'Christianise' Grotius's theory of natural law, Caspar Ziegler, Philipp Reinhart Vitriarius and William Grotius, as well as the French jurist Jean Domat, to develop his own theory of natural law. Weghorst was, moreover, undoubtedly aware of Pufendorf's position, as the citations in the work reveal. At one point Weghorst cited Pufendorf's De officio, on the issue of innate ideas, only to dismiss discussion of the issue as redundant ('supervacuum'). ${ }^{57}$ Another paragraph cites a section of Vitriarius's commentary on Grotius, which refers the reader to a part of Pufendorf's Specimen controversarium circa ius naturale, 'De origine moralitatis et indifferentia motus physici in actione humana', that discusses the distinction between entia physica and moralia. ${ }^{58}$ It would thus seem that Weghorst was consciously developing an alternative to Pufendorf's theory of natural law

naturalibus expressa.’ Ibid., I§117.

54 'in quo fine ultimo cum Homo maximam, cujus quidem in hac vita particeps esse queat, consequatur perfectionem' Ibid.

55 'Hanc ó $\mu$ oí $\omega \sigma v$ \& $\tau \varepsilon \lambda \varepsilon i ́ \omega \sigma ı v$ Homo itaq; obtinet, si Deo, sibi, \& aliis praestanda praestet, vitetq; contraria.' Ibid., I§118.

56 Ibid., I§121. Rachel also equated piety with religion and the 'duties of the first table of the Decalogue'. Ibid., I§115.

57 Weghorst, Compendii, cap. $1 \S 16$. Weghorst here also paraphrased the same passage in Aristotle's Topica (without reference) that Rachel had used in justifying the existence of first principles that should not be questioned: 'Recte Aristoteles, eum, qui Deum honorandum aut parentes amandos esse neget, non argumentis sed poena domandum dixit.' Cf. Rachel, Dissertationes, I§115.

58 Weghorst, Compendii, cap. $1 \S 8$. Referring to Philippus Reinhardus Vitriarius, Institutiones juris naturae et gentium [...] ad methodum Hugonis Grotii conscriptae (Lugduni Batavorum, 1692), chapter 1 , question 12 . 
which was becoming increasingly in vogue, and which was spearheaded in Copenhagen by his colleague Reitzer.

Grotius's theory of natural law in De iure belli fitted Weghorst's purposes in that it allowed him to argue that certain things were necessarily in accordance with 'rational nature' as an objective basis of natural law. In other words, he could use Grotius as an authority for the 'perseitas' or the inherentness of virtue and vice as the object of natural law: 'Therefore according to the opinion of Grotius there are actions necessarily conforming or contrary to rational nature, and which by their nature are prior to natural law'. ${ }^{59}$ This was a 'necessity' of the 'moral action' which was independent of the determination of any law, but which rather showed which actions the law should determine as obligatory and thus invest with a 'legal necessity'. ${ }^{60}$ Weghorst thus insisted, contrary to the Pufendorfian position, that certain moral actions, 'worshipping God' is the example given, are 'necessary in themselves apart from the obligation of law. ${ }^{61}$ As he concluded later in the same chapter: 'thus actions morally good in themselves are the foundation of natural law. ${ }^{62}$ In this regard, Weghorst positioned himself in a line of natural law theoreticians, such as Osiander, Ziegler and Vitriarius, who criticised Grotius's etiamsi daremus-principle by arguing that the obligatory force of natural law stemmed from the command of God, but likewise, in contrast to Pufendorf, argued that certain actions were good in themselves and therefore the object of natural law.

The further question, however, was in what this 'necessary conformity' with rational nature consisted, in other words, what was the 'principium cognoscendi' of natural law. Here Weghorst's theory of natural law exhibited a second of the scholastic, anti-Pufendorfian characteristics identified by Thomasius, explicitly departing from the position of Grotius (and Pufendorf) in denying that sociality (such 'actions that conserve the society of rational beings') was a sufficient basis for natural law:

59 'Ergo secundum sententiam Grotii dantur actus naturae rationali necessario convenientes aut disconvenientes, qui sui natura jus naturae antecedunt' Weghorst, Compendii, cap. $1 \S 4$.

60 Ibid., cap.1.§5.

61 'Ita cultus Dei, etiam seposita obligatione legis, in se necessarius, \& recta ratio eum homini necessario convenientem judicat' Ibid., cap. $1 \S 6$.

62 'Fundamentum itaque juris naturae, sunt actus hominum in se moraliter boni \& male' Ibid., cap. $1 \S 13$. 
As I see it, it is indubitable that those actions without which or by which society among humans is destroyed pertain to natural law. But that all the precepts of natural law have as their end that human society is maintained, I believe should be rejected. No indeed, from the following it will be clear that those precepts which seem to have as their end the maintenance of society do not have this as their final end. ${ }^{63}$

Where Grotius had secularised natural law by positing sociality as a necessary and sufficient foundation and by his etiamsi daremus-principle, and where Pufendorf had detranscendentalised natural law with his radical voluntarism, Weghorst reinforced the transcendent character of natural law and moved God centre stage by positing the love of God as the foundation of natural law:

Disregarding the opinions of others, I consider that man is created first and foremost for this end: that he should love God. And since the love of God is good in itself, God also obliges man to do so by the natural law. From this it is evident that the basis of natural law should be determined in accordance with the end of man, so that accordingly the basis of natural law is the love of God, of oneself, and one's fellow man. Of these the love of God is the foremost end. [...] Neither indeed do they err, who posit the basis of natural law solely in the love of God, for from this cannot but follow the love of men. ${ }^{64}$

This paragraph succinctly demonstrates the extent to which Weghorst's position was in line with the key doctrines of 'anti-Pufendorfian', neo-scholastic, Christian natural law identified by Thomasius. First, in the quote Weghorst emphasised the realist character of his theory of natural law, that this love of God was 'good in itself' and therefore obligatory, not the other way around. Second, Weghorst's natural law theory was indeed orientated towards the essential nature of man,

63 'Mihi equidem indubitatum est, actus ejusmodi sine quibus, aut per quos societas inter homines evertitur, ad jus naturae pertinere; at omnia juris naturalis praecepta ad hunc finem referri, ut societas inter homines salva sit, negandum esse arbitror. $\operatorname{Im}[\mathrm{m}] \mathrm{o}$ ex sequentibus patebit, praecepta illa, quae societatem tanquam finem suum tueri videntur, in eo tanquam fine ultimo non subsistere.' Ibid., cap.1.§9.

64 'Missis aliorum opinionibus existimamus, hominem primario ob hunc finem esse factum, ut diligat Deum. Cum autem dilectio Dei in se sit bona, Deus quoque hominem per jus naturae ad eam obligat. Unde apparet fundamentum juris naturae a fine hominis aestimandum, ut ita fundamentum juris naturae sit, dilectio Dei, sui ipsius, \& socii. Ex his dilectio Dei, principalis est finis. [...] Neque vero errant, qui fundamentum juris naturae in sola Dei dilectione ponunt, quippe cum hanc non possit non sequi dilectio hominis.' Ibid., cap. $1 \S 10$. 
realising the end - finis - for which man has been created. Finally, to Weghorst sociality was not the fundamental principle as it could, he argued, encompass neither man's duties to himself nor to God. ${ }^{65}$

Having appropriated Grotius's use of the perseitas-doctrine only to argue for an alternative foundation of natural law to sociality, Weghorst continued to further distinguish his position from the aspects of Grotius's position that tended towards a secularised conception of natural law. Against Grotius's argument that natural law would oblige if there was no God, he put forward a voluntarist concept of obligation. Following Caspar Ziegler, he argued that it was God as a supreme legislator that promulgated the law of nature and invested it with obligatory force. ${ }^{66}$ Nevertheless, as we have seen, God did so in accordance with the essential goodness of certain actions. In this way Weghorst adopted, again following Ziegler, the scholastic doctrine of an 'eternal law' in accordance with which God acted: 'moreover, we do not deny that the principle of this law [of nature] is the law in God, by which He Himself directs all acts and movements to their ends. See Ziegler on Grotius's Prolegomena, section "Non esse Deum etc."., 67

In determining the specific precepts of natural law Weghorst (like Rachel) first discussed the principles commonly advanced: the three established Roman law principles in Ulpian: 'honeste vivere', 'neminem laedere', and 'suum cuique tribuere' ${ }^{68}$ In his interpretation of the Roman law principles, Weghorst drew on Aristotelian virtue ethics: 'of these principles we consider the foremost of all to be that we live honourably [honeste vivere]. For to live honourably is to practice any duty of love, be it towards God or man [...] and in this [principle] the precepts of all the virtues are contained. ${ }^{69}$ In the end, however, he settled on a different set of principles more in accordance

65 Ibid., cap.1.§12.

66 Ibid., cap. $1 \S 14$.

67 'Alioqui non negamus principium hujus juris esse legem in DEO, per quam ipse omnes actus ac motus in suos fines dirigit. Add. Ziegl. ad Grot. in proleg. Vers: Non esse Deum \&c.' Ibid., cap.1§15. Ziegler has the following: 'Interim tamen hoc non nego esse en Deo aeternam aliquam legem, hoc est rationem divinae sapientiae, directivam omnium actionum $\&$ motuum in suos fines, $\&$ jus aliquod naturale immanens antecedenter ad omnem liberum voluntatis actum, secuncum quod non potest velle juri illi repugnat.' Kaspar Ziegler, In Hugonis Grotii De Iure Belli Ac Pacis Libros, Quibus Naturae \& Gentium Ius Explicavit, Notae \& Animadversiones Subitariae (Wittebergae, 1666), $7 \mathrm{f}$.

68 Weghorst, Compendii, cap. $2 \S 1$.

69 'Ex his primum omnium principium existimamus esse, honeste vivere. Est enim honeste vivere, 
with the theory of the love of God as the foundation of natural law that he had developed in the previous chapter: '(1) love in the proper way. (2) love God from your heart. (3) love your fellow man as yourself.' The love of God, moreover, could be considered specifically as what was His due and generally as doing everything which God has commanded, including the totality of one's duties according to natural law. ${ }^{70}$

The final chapter discussed the duties specifically towards God: the right knowledge, or contemplation, of God and the worship (cultus) of God which Weghorst comprehended under the concept of piety (pietas). Although Weghorst concluded the work with the remark that he had shown the knowledge philosophy could obtain although divorced from Christian faith, his position in this regard was ambiguous. For Weghorst also warned that although it was not the place to explain how God should be contemplated 'according to divine revelation', in fact it was 'not within our powers to comprehend God by means of reason'. ${ }^{71}$ Therefore, one should beware not to be led astray by reason, and 'the knowledge of God should be sought in such a way that reason is contained within the bounds of worship, veneration and fear. ${ }^{72}$

Weghorst's Compendium on natural law was an independent work although it shares a number of characteristics with the kind of natural law Samuel Rachel had taught (without referring to him). Weghorst followed Grotius precisely on those issues where the latter had retained scholastic doctrines also found in Rachel: the notion of the perseitas of good and evil and an eternal law in accordance with which God obligated man through natural law. Moreover, where Weghorst was the most original in relation to his intellectual background, positing the love of God rather than sociality as the foundation of the law of nature, this had the effect of emphasising the Christian and transcendent aspects of his theory of natural law even further.

quodvis amoris officium exercere; sive illud exhibendum sit Deo, sive homini [...] Unde hoc principio omnia virtutum praecepta continentur.' Ibid., cap. $2 \S 2$.

70 Ibid., cap. $2 \S 6-7$; and cf. Rachel above at note 58.

71 Ibid., cap. $3 \S 7$.

72 'Cum nostrorum virium non sit, DEum ratione assequi, cavendum esse, ne proprius accedamus ad lucem illam inacessim, ne radiorum fulgore obruamur. Ita enim cognitio Dei appetenda, ut intra cultus, venerationis \& timoris concellos ratio contineatur.' Ibid., cap. $3 \$ 7$. 


\section{Perspectives into the eighteenth century}

Seen against the background of the official theological divine right ideology in Denmark-Norway and Masius's explicit rejection of the discipline of natural law divorced from revelation, both Weghorst and Reitzer may be said to have broken new ground. ${ }^{73}$ However, as has been shown, they did so in very different ways that indicate the range of discourses on natural law in the early Danish enlightenment. By drawing on and presenting the anti-scholastic natural law theories of Pufendorf and Thomasius, Reitzer's Positionum constituted a fundamental criticism of the intellectual underpinnings of the confessional state most radically represented by Masius in Denmark-Norway. Weghorst, for his part, developed a theory of natural law that, while not as extreme as Masius, criticised the secularising tendencies in Grotius and Pufendorf and reiterated many of the central doctrines of scholastic natural law.

In the first place Weghorst's more conservative 'Christian natural law', and thus the legacy from Kiel, won out over Reitzer's attempts to introduce the Halle school of natural law into the university of Copenhagen. It was Weghorst and not Reitzer who taught natural law and moral philosophy at the University in the first decades of the eighteenth century. Where, according to the lecture catalogue, Reitzer focused on Danish law, Weghorst lectured on Grotius's De iure belli ac pacis $1710-17$ and on moral philosophy from 1710 to his death in $1722 .{ }^{74}$ Weghorst continued to develop his theory of natural law to underpin a moral philosophy in opposition to the Pufendorfian position. Like his Compendium from the 1690s his later works argued for the existence of a bonum morale independent of law, in particular the love of God for which man was first and foremost created, combining this with an Aristotelian catalogue of virtues. ${ }^{75}$ This competition between Reitzer's and Weghorst's theories of natural law and political theories also found echoes in university disputations. A 1709 university dissertation contrasted the notion that the state was created for the sake of utility, which the author attributed to Pufendorf, with a definition of the state, which Weghorst had 'given in a public lecture', as a natural society aiming at the 'bonum commune' over and above civil utility. ${ }^{76}$

73 For a succinct account of Maius's place in official royal ideology, see Olden-Jørgensen, 'Scandinavia', $324-6$.

74 Lectiones publicae Professorum in Universitate Hauniensi.

75 Henrik Weghorst, Labyrinthus moralis, juri naturali pervius, cujus duas partes cum adjecto virtutum hortulo (Hafniae, 1713), the second part of which is entitled 'de bono morali ante legem'.

76 Christian Ramus, Dissertatio historico-politica prima, de prima civitatum origine earumqve 
Weghorst's moral philosophy and theory of natural law were, however, not completely hegemonic in the intellectual life of the Danish-Norwegian capital. It is well known that Reitzer, whose extensive library provided a focal point for a large and diverse circle of enlightenment thinkers, ${ }^{77}$ encouraged Ludvig Holberg to write his Danish introduction to natural law. The work, published in 1716, followed Pufendorf's theory of natural law to a large extent and became very popular, going through several editions in the eighteenth century. The findings presented in this article should, however, serve to caution against too readily assuming that this work was representative of the political ideology of the time, and highlight the need to ask precisely what kind of Pufendorfian natural law was developed and what its precise position in the DanishNorwegian context was. ${ }^{78}$ Thus it has been pointed out that Holberg passed over Pufendorf's doctrine of the distinction between entia physica and moralia in silence. ${ }^{79}$ A reason for this may have been that this doctrine was closely connected to Pufendorf's criticism of a 'bonum morale ante legem', the position which, as we have seen, Weghorst was championing in those years.

That this arose perhaps not entirely from strategic considerations on Holberg's part is brought out in a controversy over the marriage between close relatives that broke out a few years later; a controversy which also showed some of the wider religious-political issues at stake in the competition between different forms of natural law. The controversy surrounded a dissertation that the young Andreas Hojer (1690-1739) from Schleswig had written while in Helmstedt and published in Lemgow, Germany in $1718 .{ }^{80}$ Hojer had studied under Christian Thomasius in 1707-9 and drew on Thomasius's theory of natural law to argue that marriage between closely related was

constitutione (Hafniae, 1709), fol. A3v.

77 For an account of this circle, see Martin Mulsow, 'Freethinking in Early Eighteenth-Century Protestant Germany: Peter Friedrich Arpe and the "Traité Des Trois Imposteurs", in Heterodoxy, Spinozism, and Free Thought in Early Eighteenth Century Europe, ed. Silvia Berti, Françoise Charles-Daubert, and Richard Popkin (Dordrecht, 1996), 204-8.

78 For this question, see Haakonssen, 'Holbergs Pufendorf - men hvilken Pufendorf?'. For an answer, see Knud Haakonssen, 'The Law of Nature and Nations', in Ludvig Holberg (1684-1754). Learning and Literature in the Nordic Enlightenment, ed. Knud Haakonssen (forthcoming 2016), 2-24. I am grateful to Knud Haakonssen for allowing me to read, and cite, this manuscript.

79 Haakonssen, 'The Law of Nature and Nations', 3, 9f.

80 Andreas Hojer, De nuptiis propinquorum iure divino non prohibitis (n.p, n.d.). For an account of the work and the controversy with Holberg in particular, see Haakonssen, 'The Law of Nature and Nations', 15-17; Troels G. Jørgensen, Andreas Hojer, jurist og historiker (København, 1961), 40-54. 
not prohibited by natural law in a strict sense nor by positive divine law (although it was contrary to Christian perfection), and was only prohibited by the positive laws of the sovereign in the interest of social order. ${ }^{81}$ Hojer, a longtime rival of Holberg, returned to Copenhagen to pursue a career there, and the pamphlet was brought to the attention to some of the professors of theology. Hojer was summoned for interrogation by the professors, and Holberg wrote a pamphlet under pseudonym criticising Hojer's arguments.

The difference between Holberg's and Hojer's positions, both considered proponents of Pufendorfian and Thomasian natural law, is illustrative of the different ways this form of natural law was appropriated and used. Holberg first of all declared that he would leave the issue of divine positive law to the judgement of the theologians, the proper authorities on the subject. ${ }^{82}$ With regard to his arguments concerning the natural legal prohibition, his position has been characterised as partly 'a turn towards a substantial 'naturalism' that is a complete lapse from his Pufendorfian principles [...] Holberg used 'nature' and 'the natural' as normative concepts in themselves'. ${ }^{83}$ In other words, Holberg was here much closer to Weghorst's position that certain things were morally bad per se, 'ante legem'. During the investigation by the theologians and the letters he sent to the king in his defence, Hojer, on his part, maintained his position that such marriage was not prohibited by natural law strictly speaking 'in so far as it derives from socialitas', arguing further that such issues were discussed freely in Germany and, moreover, that the theologians for the most part lacked the requisite knowledge to understand the issue. Instead he asked that the opinions of the professors of law, which included Reitzer, as well as Christian Heinrich Amthor, another follower of Christian Thomasius, former professor of natural law in Kiel and now Royal Historian in Copenhagen, be requested as the proper authorities on natural law. ${ }^{84}$

81 Hojer, De nuptiis propinquorum, 84f.

82 Ludvig Holberg, Dissertatio juridica de nuptiis propinquorum in linea recta jure naturali prohibitis (Rostock, 1719), 2.

83 Haakonssen, 'The Law of Nature and Nations', 16f.

84 The report of the theological faculty of the interrogation as well as Hojer's letters, are printed in Holger Rørdam, Historiske Samlinger, vol. 2 (Kjøbenhavn, 1896), 319-359, pp. 332 and 336f. for Hojer's requests that the King seek the opinions of lawyers and Amthor as the proper authority on natural law. For Amthor, see the entry in Heiner F. Klemme and Manfred Kuehn, eds., The Bloomsbury Dictionary of Eighteenth-Century German Philosophers (New York, 2004). 
According to Hojer's letters, both Amthor's and Reitzer's opinions were favourable to Hojer's case, ${ }^{85}$ and not only were no further measures taken against him, he was employed in a string of public positions throughout the 1720s. Perhaps the ultimate vindication of Hojer came with his appointment to the new professorship in the law of nature and of nations in 1734 . Here, in a public disputation later published in Latin as well as a Danish translation, Hojer warned his young students against the doctrines 'that actions are good or bad independently of divine will, and that the just and the morally good are the same and would obligate even if God did not exist. ${ }^{96}$ This did not mean, however, that Pufendorfian-Thomasian natural law had finally attained hegemony. For now, the opponents defending these doctrines were Christian Wolff and his disciples.

\section{Conclusion}

Existing scholarship has described the history of natural law in early enlightenment DenmarkNorway as the story of the introduction of 'modern' natural law derived from Grotius and Pufendorf in the generation around 1700. In contrast, this article has argued that the decades around 1700 in fact saw the rivalry and competition between significantly different traditions within post-Grotian natural law. Moreover, in so far as the Danish writers on natural law were following either Grotius or Pufendorf, they had been received and reinterpreted through local discourses of natural law: Rachel's 'Christian natural law' in Kiel in the case of Weghorst, and Thomasius's Pufendorfian natural law in Halle in the case of Reitzer. That these theories entailed far-reaching consequences for the understanding of religious, social and political matters, and who had the authority to determine these, has only briefly been hinted at in discussing the controversy surrounding the young Andreas Hojer.

The findings of this article suggest that rather than a successive series of periodisations, such as confessional divine right theory, over 'modern' natural law, to Montesquieuian political

85 In his account of the affair, Hojer wrote: 'Die Juristen haben zwar positiver [than the theologians] und jeder nach seinem Begriff geurtheilet, doch hoffe ich nicht, dasz einer von ihnen meine Sätze werde vor strafbahr oder verdammlich gehalten haben, da ich vielmehr weisz, dasz die Justitz Rähte Reitzer und Amthor mit meiner Schrift gar friedlich gewesen.' Rørdam, Historiske Samlinger, II, 351.

86 'dogmata de actionibus antecedenter ad voluntatem divinam bonis aut malis. Nec non de Justo atque honesto, etiam si Deus non esset, tamen obligante, \& eodem', Andreas Hojer, Ideae Iurisconsulti Danici partem 1 disputatione anniversaria expositam (Hafniae, 1736), 25. 
theory, the intellectual and political history of early enlightenment Denmark-Norway is best told as the history of authors, teachers and political actors using, adapting and developing a wide variety of political discourses for a variety of purposes. The reception of Pufendorf's and Thomasius's theories of natural law and their wider intellectual and political consequences, as well as other forms of natural law theory, largely remains to be told. By showing the diversity of natural law theorising as early as the $1690 \mathrm{~s}$, the present article has sought to open this as an area of further research. 